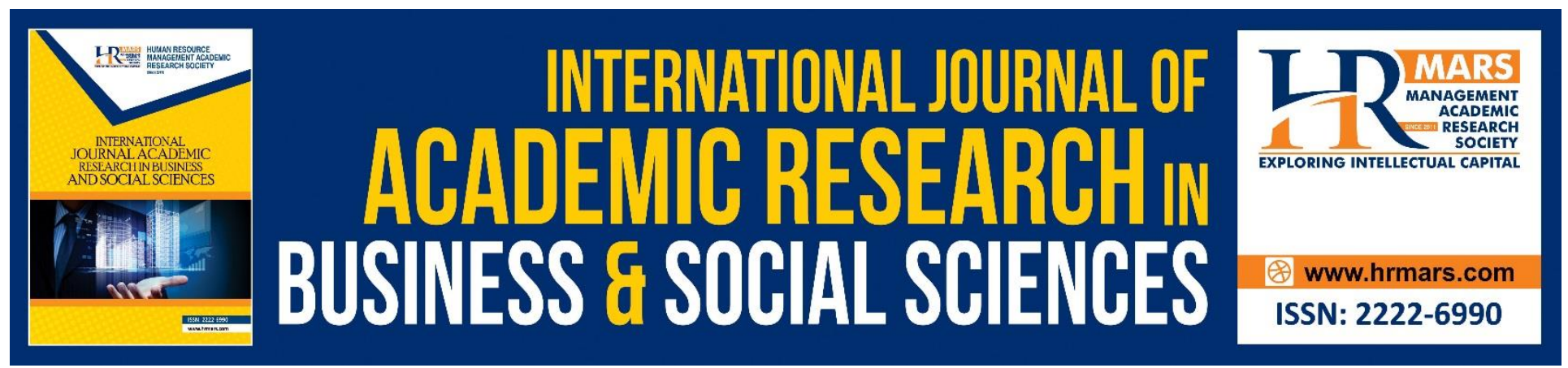

\title{
The Level of Digital Games Usage among of Practicum Student during Teaching Practice
}

\author{
Md. Nasir Masran, Siti Zainab Ayob
}

To Link this Article: http://dx.doi.org/10.6007/IJARBSS/v10-i7/7615

DOI:10.6007/IJARBSS/v10-i7/7615

Received: 22 April 2020, Revised: 18 June 2020, Accepted: 29 June 2020

Published Online: 20 July 2020

In-Text Citation: (Masran \& Ayob, 2020)

To Cite this Article: Masran, M. N., \& Ayob, S. Z. (2020). The Level of Digital Games Usage among of Practicum Student during Teaching Practice. International Journal of Academic Research in Business and Social Sciences, 10(7), 845-851.

Copyright: (C) 2020 The Author(s)

Published by Human Resource Management Academic Research Society (www.hrmars.com)

This article is published under the Creative Commons Attribution (CC BY 4.0) license. Anyone may reproduce, distribute, translate and create derivative works of this article (for both commercial and non-commercial purposes), subject to full attribution to the original publication and authors. The full terms of this license may be seen at: http://creativecommons.org/licences/by/4.0/legalcode

Vol. 10, No. 7, 2020, Pg. 845 - 851

Full Terms \& Conditions of access and use can be found at http://hrmars.com/index.php/pages/detail/publication-ethics 


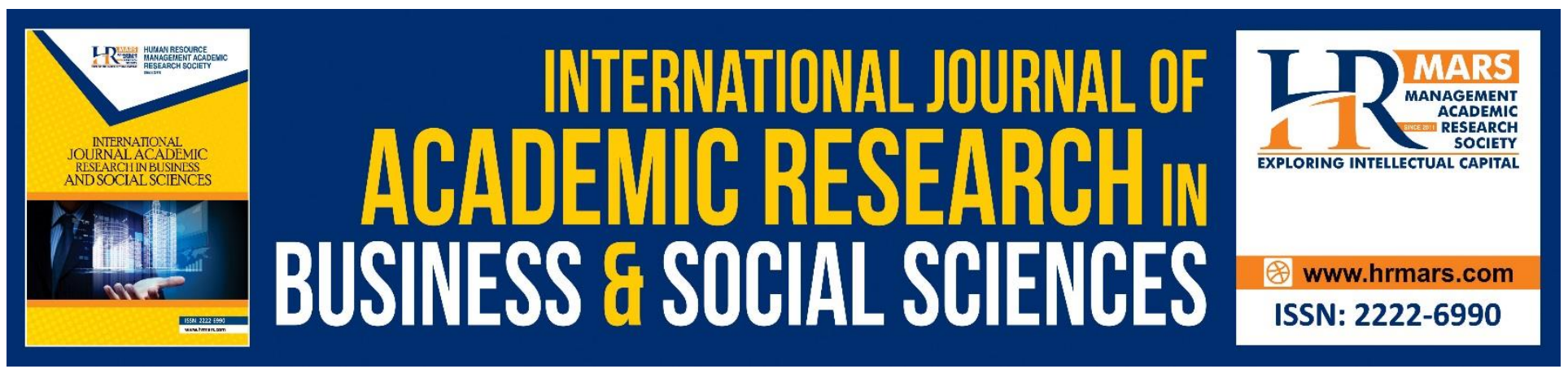

\title{
The Level of Digital Games Usage among of Practicum Student during Teaching Practice
}

\author{
Md. Nasir Masran, Siti Zainab Ayob \\ Faculty of Human Development, Sultan Idris Education University, 35900 Tanjong Malim, Perak, \\ Malaysia \\ Email: M.Nasir@fpm.upsi.edu.my,ctzainab.kje@gmail.com
}

\begin{abstract}
The objective of this research is to find out the digital technology competency and usage of digital games in lessons for disabilities students among special education trainee teachers. The lessons were conducted by special education trainees during their teaching practice. This study utilized quantitative and qualitative methods and data was gathered through questionnaire, observation survey, document analysis and interviews. The study involved 11 teaching Special Education trainees doing teaching practice in the states of Perak and Selangor and their guidance teachers. The quantitative data were analyzed by descriptive analysis using the Statistical Package for the Social Sciences while the interviews were transcribed. The result of this study shows that the frequency of digital games usage was at a moderate level with an overall mean value of 3.09 and standard deviation of 0.80 . This result was supported by observational survey data that shows that the use of digital games is at a moderate level too. The item with the highest value was the usage of laptop / LCD / projector at 3.91. While the items with the lowest mean value were items using online quizzes, 'arcade games', 'puzzle games', 'management games', 'adventure games', and 'role playing games' with a mean of 2.00 and standard deviation of 1.01 This findings was supported by the findings of the observational survey which is also at a moderate level with a mean of 3.09 and a standard deviation of 0.801 . Therefore, this study identifies the level of usage of digital games by special education trainee students during their teaching practice sessions. It was suggested that the trainee teachers should be encourage to use digital games more frequently during their teaching practice.
\end{abstract}

Keywords: Digital Games, Practicum Students, Teaching Practice, Learning Disabilities.

\section{Introduction}

The significant of digital games in education is the quality of their learning outcomes (Allsop et al, 2016). Digital games are one of the most popular element among children and adolescents. Therefore, the application of the education system using digital games techniques is very flexible and appropriate to date. These elements have the advantage of applying principles of learning that are at the core of education such as the application of a variety of elements as noted in behavioral theory, 
cognitive theory, and constructive theory. Jessel (2012) states that innovation will increase in line with the widespread development of technologies that help improve the skills of a teacher.

Educational games are an informal learning strategies that involves technology in education (Echeverria et al., 2011). This is because it attracts students to actively engage in the learning process. Games in education are also a teaching tool for learning without forcing student to learn (Birova, 2013). This is because the use of games while learning has a positive effect on the motivation of the students who use them. Students' focus and interest on learning increases throughout the use of games in the classroom.

\section{Problem Statement}

This aim of the study are to identify digital games usage by special education students during their teaching practice. Special Education children are often associated with problems in learning. Their low level of functioning during lessons such as not being able to focus, passive and over active are issues needed to be overcome by the trainee teachers. Various suggestions were made to make teaching and learning more interesting among special education students such as by applying multimedia that integrate text, sound effects, vocals, music, animation, video and interactive computer software ( Jasmi, Tamuri \& Hamzah, 2011). The use of digital games is one of the ways in which special education students can stay focused and motivated during classroom sessions. This study aims to identify the level of digital games usage among special education teachers in secondary school.

\section{Research Objectives}

The objective of this study is to:

a) Find out the level of competency in digital technology among special education teacher trainees.

b) Find out the level of digital games usage among special education teacher trainees during their teaching practice.

\section{Research Questions}

a) To what extent do Special Education trainee teachers often use digital games in their lessons during teaching practice?

b) What is the level of competency in digital technology among special education teacher trainees.

\section{Research Methodology}

This study is a survey study. The findings of this study having qualitative data and quantitative data. For qualitative data, interviews and document analysis were used to see the level of digital use by teaching practicum students by interviewing the instructor teachers. The data were analyzed using inductive thematic analysis and presented descriptively. While, quantitative data use through a practical student questionnaire were analyzed using the Statistical Package for the Social Science (SPSS) and presented in the form of descriptive data. 
INTERNATIONAL JOURNAL OF ACADEMIC RESEARCH IN BUSINESS AND SOCIAL SCIENCES

Vol. 10, No. 7, July, 2020, E-ISSN: 2222-6990 @ 2020 HRMARS

\section{Limitation of the Study}

This study has some limitations. The study is aimed only for special education practicum students of University Pendidikan Sultan Idris. The study was conducted in the state of Perak to get the statistic result.

\section{Research Design}

This study is a survey of digital games usage among special education trainee teachers. Qualitative and Quantitative data were gathered through questionnaires, observation survey and interview sessions. Interview transcripts were analysed using the thematic analysis is presented descriptively. Meanwhile, the quantitative data was analysed through the Statistical Package for the Social Science (SPSS) and is presented in the form of descriptive statistics.

\section{Respondents}

The study involves Special Education Bachelor Degree program students who are undergoing practicum. This study comprises of eleven practicum teachers in Perak and Selangor. The practicum teacher was guided by mentors serving in Special Education classes.

\section{Research Findings}

The Competency Level of Digital Games's Technology Among of Practicum Students.

This section addresses the objectives of the study of aspects of the students' practical knowledge of digital games.

\begin{tabular}{|c|c|c|c|c|}
\hline \multirow[b]{2}{*}{ Questionnaire items } & \multicolumn{2}{|r|}{ (Student) } & \multicolumn{2}{|r|}{ (Observer) } \\
\hline & Min & $\begin{array}{c}\text { S.Deviatio } \\
\mathrm{n}\end{array}$ & Min & S.Deviation \\
\hline Practical Teacher's & 4.1 & 0.431 & 3.36 & 0.723 \\
\hline $\begin{array}{l}\text { Competency of Digital } \\
\text { Games Technology. }\end{array}$ & 9 & & & \\
\hline
\end{tabular}

Table 1: Mean difference in mean and standard deviation of practicum student's knowledge data

In terms of mastering the digital games technology competency, analysis of questionnaire data distributed to practicum students with mean value of 4.19 and standard deviation 0.43 . It shows that practicum students choose to have a high level of proficiency in technology while undergoing practicum. However, based on observational survey it is found that students have a lower level of digital games technology competency with a mean of 3.36 and a standard deviation of 0.723 . This indicates that practicum students rated themselves higher in digital games technology competency than the observers rating. 


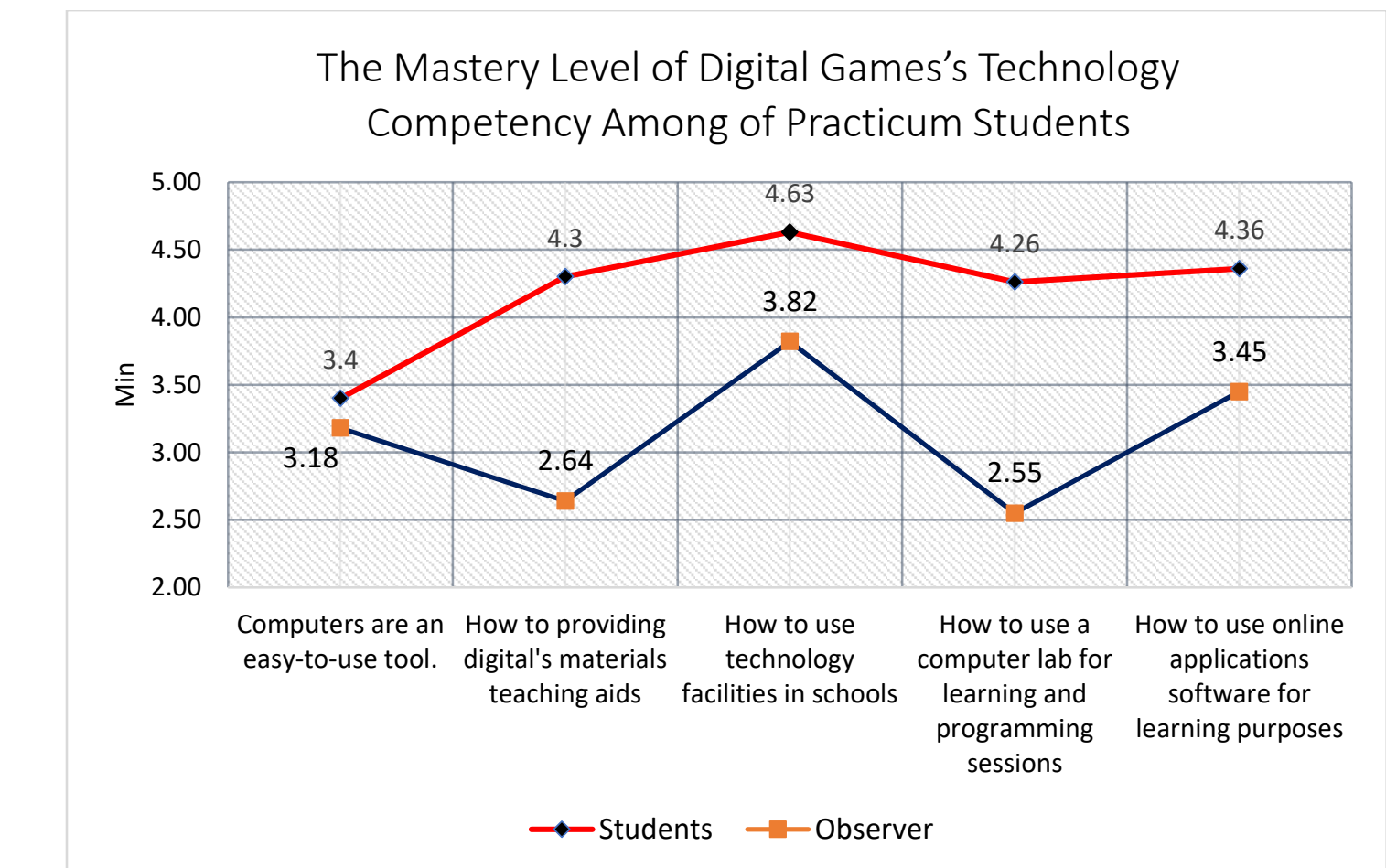

Diagram 1 : The Level Mastery of Digital Games's Technology Competency Among Practicum Students

Section II: Frequency of Use of Digital Games by Practicum Students

This section addresses the objectives of the study of how often students practice using digital games.

\begin{tabular}{ccc|cc}
\hline Questionnaire items & \multicolumn{2}{c|}{ (Student) } & \multicolumn{2}{c}{ (Observer) } \\
& & $\begin{array}{c}\text { S.Deviatio } \\
\mathrm{n}\end{array}$ & Min & S.Deviation \\
\hline Frequency of Digital Games Use & 3.29 & 0.481 & 3.09 & 0.801 \\
\hline
\end{tabular}

Table 2: Mean difference and standard deviation of data frequency of digital games used by practical students

According to the table, the mean score of the questionnaire on the frequency of digital games usage by the practicum students was 3.29 and the standard deviation was 0.481 indicating that the students had a moderate level of frequency of digital games usage. It states that practicum students do not use digital games regularly in the classroom for special education students. Thisd finding is supported by the findings of the observational survey which is also at a moderate level with a mean value of min 3.09 and a standard deviation of 0.801. 
INTERNATIONAL JOURNAL OF ACADEMIC RESEARCH IN BUSINESS AND SOCIAL SCIENCES Vol. 10, No. 7, July, 2020, E-ISSN: 2222-6990 @ 2020 HRMARS

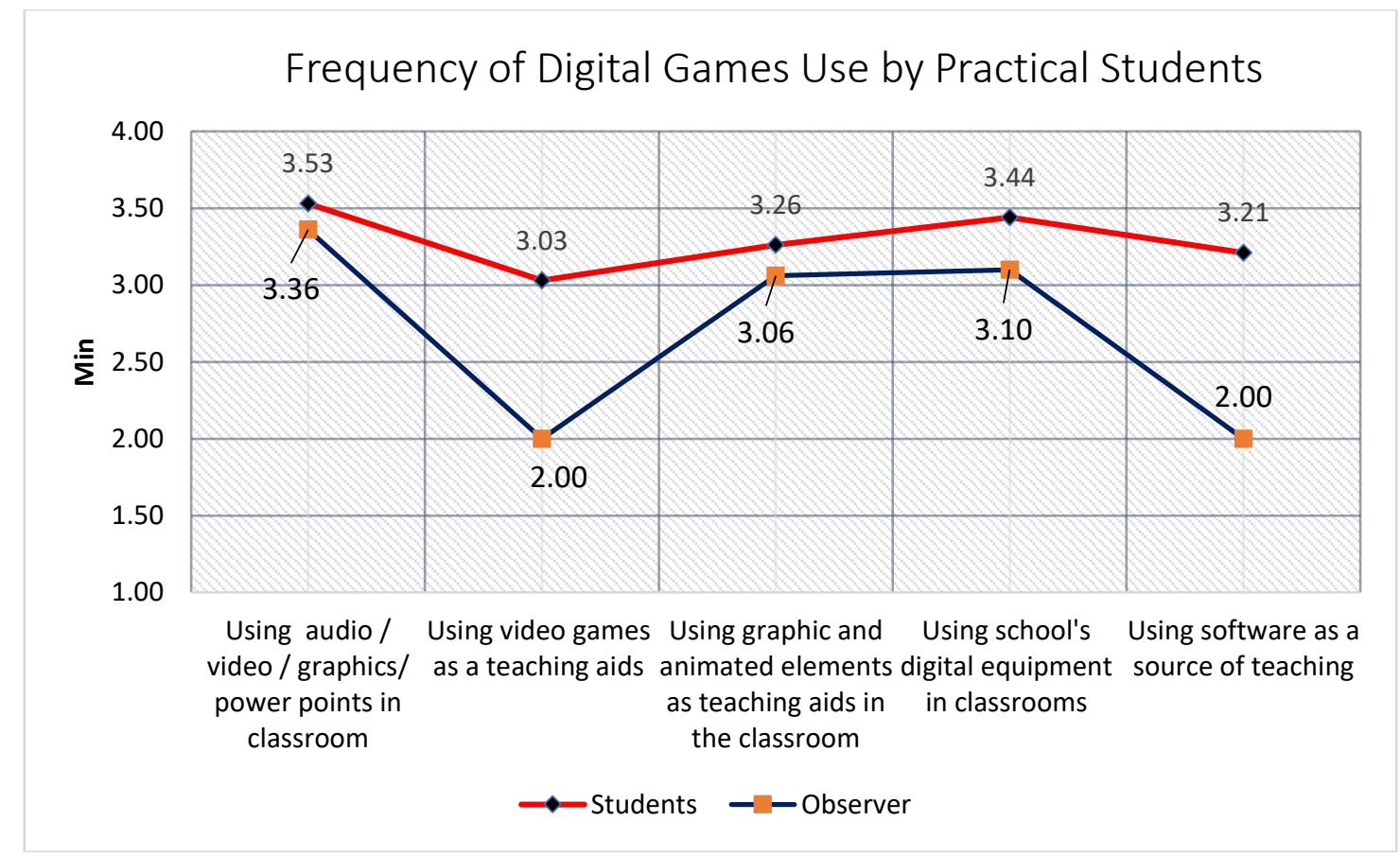

Diagram 2: Frequency of Digital Games Use by Practical Students

\section{Conclusion}

This study aims to identify the level of digital games usage and competency of digital games technology among Special Education trainee teachers in schools. Therefore, future teachers will need to prepare themselves with comprehensive knowledge and skills in various aspects of digital games technology competency to ensure that they are able to educate students well.

However, there are many challenges when using digital games in teaching. As an innovative teacher, teachers were expected to come up with new ideas that will help them to successfully motivate special education students to learn.

\section{Corresponding Author}

Associate Professor Dr. Md Nasir bin Masran, Puan Noreha binti Md Yusof and Siti Zainab binti Ayob from Faculty of Human Development, Research Management Industry Centre, Sultan Idris Education University, 35900 Tanjong Malim, Perak, MALAYSIA. This paper is based on the research project entitled "Penggunaan Permainan Digital oleh Pelajar Praktikum Terhadap Golongan Berkeperluan Khas". The authors would like to extend their gratitude to the Research Management and Innovation Centre (RMIC), Sultan Idris Education University (UPSI) for the University Research Grants (code: 2018 - 0236-107-01) that helped fund the research. Email:md.nasir@fpm.upsi.edu.my.

\section{References}

Allsop, Y., Yildirim, E. Y., \& Screpanti, M. (2013). Teachers' beliefs about game-based learning; a comparative study of pedagogy, curriculum and practice in Italy, Turkey and the UK. Proceeding of the $7^{\text {th }}$ European Conference on Games Based Learning 2, 1-10.

Birova. (2013). Game as a main strategy in language education. American Journal of Educational Research, 1(1), 6-10. 
INTERNATIONAL JOURNAL OF ACADEMIC RESEARCH IN BUSINESS AND SOCIAL SCIENCES

Vol. 10, No. 7, July, 2020, E-ISSN: 2222-6990 @ 2020 HRMARS

Echeverria, A., Garcia-Campo, C., Nussbaum, M., Gil, F., Villalta, M., Amestica, M., Echeverria, S., (2011). A framework for the design and integration of collaborative classroom games. Computers \& Education. 57(1), 1127-1136.

Jasmi, K. A., Tamuri, A. H., \& Hamzah, M. I. (2011). Kajian Kes Penggunaan Kaedah Pengajaran Dan Pembelajaran Guru Cemerlang Pendidikan Islam (GCPI) Sekolah Bandar Dan Luar Bandar: Satu Kajian Perbandingan. Jurnal Teknologi, 56(1). doi:10.11113/jt.v56.66 